\title{
Bermudagrass for Florida Lawns ${ }^{1}$
}

\author{
Laurie E. Trenholm, Marco Schiavon, J. Bryan Unruh, and Travis W. Shaddox ${ }^{2}$
}

Bermudagrasses (Cynodon spp.) are among the most widely used warm-season grasses. Improved, fine-textured bermudagrasses are used throughout the south on golf courses, athletic fields, and in high-profile residential and commercial landscapes where a fine-textured, dense ground cover is desired. Generally, these are hybrids of common bermudagrass (Cynodon dactylon) and African bermudagrass (Cynodon transvaalensis). However, improved cultivars of common bermudagrass are available that can produce a nice lawn in full-sun situations. These bermudagrass varieties have coarser leaves and generally do not provide the high-quality carpeted look nor do they require the high maintenance of the fine-textured types. This publication is intended for homeowners and turfgrass and landscape managers that manage bermudagrass in Florida landscape.

\section{Advantages}

Bermudagrass produces a vigorous, medium-to-dark green, dense turf that is well adapted to most soils and climates found in Florida. Bermudagrass has excellent wear, drought, and salt tolerance and can withstand low temperatures by transitioning into dormancy. It establishes rapidly and can outcompete most weed species. It is readily available as sod or sprigs, and some improved cultivars are available as seeded varieties. Bermudagrass offers one of the best turfgrass options for persistence in situations where any form of irrigation (automatic or manual hose-applied) is not available.

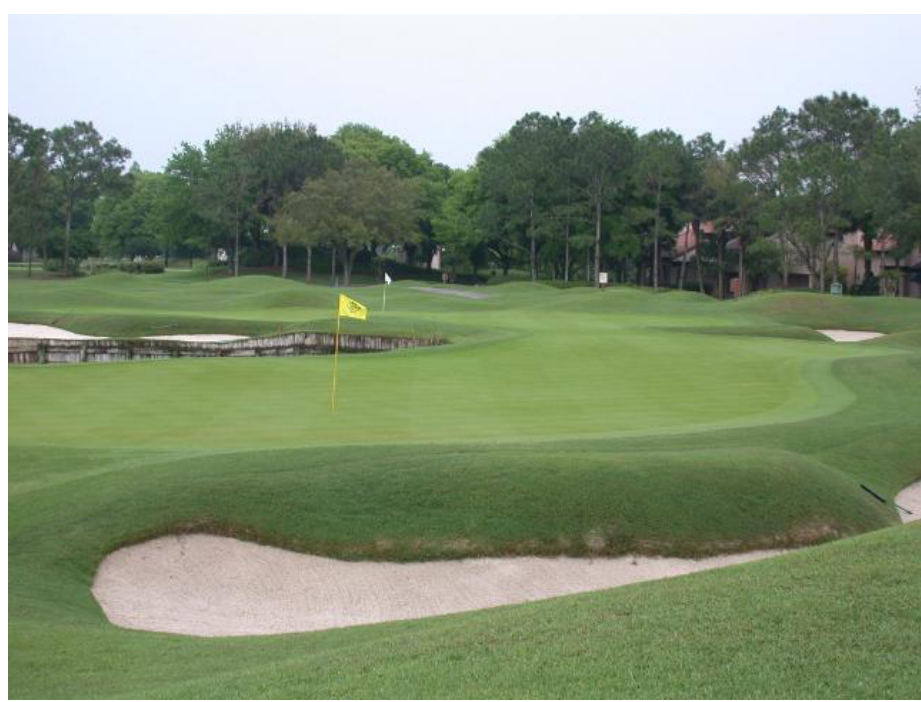

Figure 1. Hybrid bermudagrass used on a golf course. Credits: J. Bryan Unruh, UF/IFAS

\section{Disadvantages}

Bermudagrass cultivars commonly used in golf course and athletic field settings require higher levels of maintenance than other grasses typically used for home lawns. They have poor tolerance to many insect, disease, and nematode pests, which can limit their use. They grow very aggressively from stolons (aboveground stems) and rhizomes (belowground stems) and can rapidly invade flower and landscape beds. This aggressive growth also fosters thatch buildup. Bermudagrasses will generally not maintain green color in cold temperatures and have poor shade tolerance.

1. This document is ENH19, one of a series of the Environmental Horticulture Department, UF/IFAS Extension. Original publication date May 1991. Revised August 2021. Visit the EDIS website at https://edis.ifas.ufl.edu for the currently supported version of this publication.

2. Laurie E. Trenholm, retired professor, Environmental Horticulture Department; Marco Schiavon, assistant professor, turf \& sod, Environmental Horticulture Department, UF/IFAS Ft. Lauderdale Research and Education Center, Davie, FL; J. Bryan Unruh, professor and associate center director, Environmental Horticulture Department, UF/IFAS West Florida REC, Jay, FL; and Travis W. Shaddox, former assistant professor of turfgrass, Environmental Horticulture Department, UF/IFAS Ft. Lauderdale REC, Davie, FL; UF/IFAS Extension, Gainesville, FL 32611.

The Institute of Food and Agricultural Sciences (IFAS) is an Equal Opportunity Institution authorized to provide research, educational information and other services

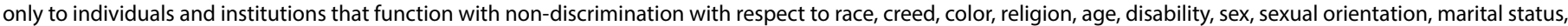
national origin, political opinions or affiliations. For more information on obtaining other UF/IFAS Extension publications, contact your county's UF/IFAS Extension office. U.S. Department of Agriculture, UF/IFAS Extension Service, University of Florida, IFAS, Florida A \& M University Cooperative Extension Program, and Boards of County Commissioners Cooperating. Nick T. Place, dean for UF/IFAS Extension. 


\section{Vegetatively Propagated (Sod and Sprigs) Cultivars \\ 'Tifway,'TifGrand,' and 'TifSport'}

These hybrid cultivars are commonly used in golf and athletic fields. These cultivars will require increased levels of maintenance (i.e., greater nutrition and plant protectant chemicals, increase mowing frequency, etc.) and may be best managed by professional lawn care companies. 'TifGrand' requires fewer hours of direct sun and is less sensitive to the Tawny-mole cricket compared to 'Tifway' and 'TifSport'.

\section{'Latitude 36”}

'Latitude 36 ' is a relatively new hybrid cultivar developed at Oklahoma State University. It is noted for its ability to survive colder climates compared to other bermudagrasses. It is also more resistant to spring dead spot. Latitude 36 is available in Florida and is performing well, however is prone to nematode injury. It is not as aggressive as other bermudagrasses.

\section{'TifTuf'}

This is a new hybrid cultivar from the University of Georgia. This bermudagrass is very drought tolerant but will require levels of maintenance similar to 'Tifway,' 'TifGrand,' and 'TifSport.' 'TifTuf' is also proving to retain color longer into the fall, and its shade response is similar to 'TifGrand'

\section{'Celebration'}

'Celebration' bermudagrass is a versatile variety that is used on golf courses, athletic fields, and home lawns. It has a fine leaf texture and quality but does not require as much maintenance as some of the other fine textured bermudagrass cultivars. It has good tolerance to traffic and will tolerate slightly more shade than other bermudagrasses. Celebration can be mowed at 1"-2" for lawn use and a rotary mower can be used. Mowing at heights $>2$ " may result in an uneven appearance.

\section{'Bimini'}

'Bimini' bermudagrass is very new to the Florida market. Its growth habit is intermediate between 'Celebration' and the hybrid cultivars. It has been well received in the golf market, and early evidence supports its use in a variety of applications: golf, athletic fields, and home lawns. Mowing requirements will be similar to 'Celebration'.

\section{'NorthBridge'}

Like 'Latitude 36', 'NorthBridge' was developed at Oklahoma State University. This is a cold tolerant bermudagrass variety that possesses early Spring green-up, hence will come out of dormancy and regain green color early in the spring.

\section{'PremierPRO'}

'PremierPRO' is a fine texture hybrid developed at Texas A\&M University. Currently available only in South Florida, this grass can be used on golf courses, athletic fields and homelawns. Mowing recommendations range from 0.5 to 2.5 inches. 'PremierPRO' shows aggressive lateral growth that helps with rapid establishment and injury recovery.

\section{Seeded Cultivars}

Retail stores routinely sell seeded cultivars of common bermudagrass (Figure 2). Two seeded varieties that have performed well throughout Florida are Princess 77 and Sultan. You often find blends of two or three varieties that may include cultivars such as 'Arizona Common', 'Riviera', 'Cheyenne, 'Sahara,' 'Sundevil', 'Jackpot', and others. The varieties contained in these seed packages can change from year to year based on seed availability. These improved seeded varieties have a darker green color, deeper roots, more shoot density, and a less coarse leaf texture than older selections of common bermudagrass (e.g., Arizona Common). While these varieties are suited for lawns, sports turf, parks, or roadsides, their performance and overall quality are generally lower than the vegetatively propagated cultivars. It is worth noting that the performance of these blends of bermudagrass have not been evaluated by the University of Florida.

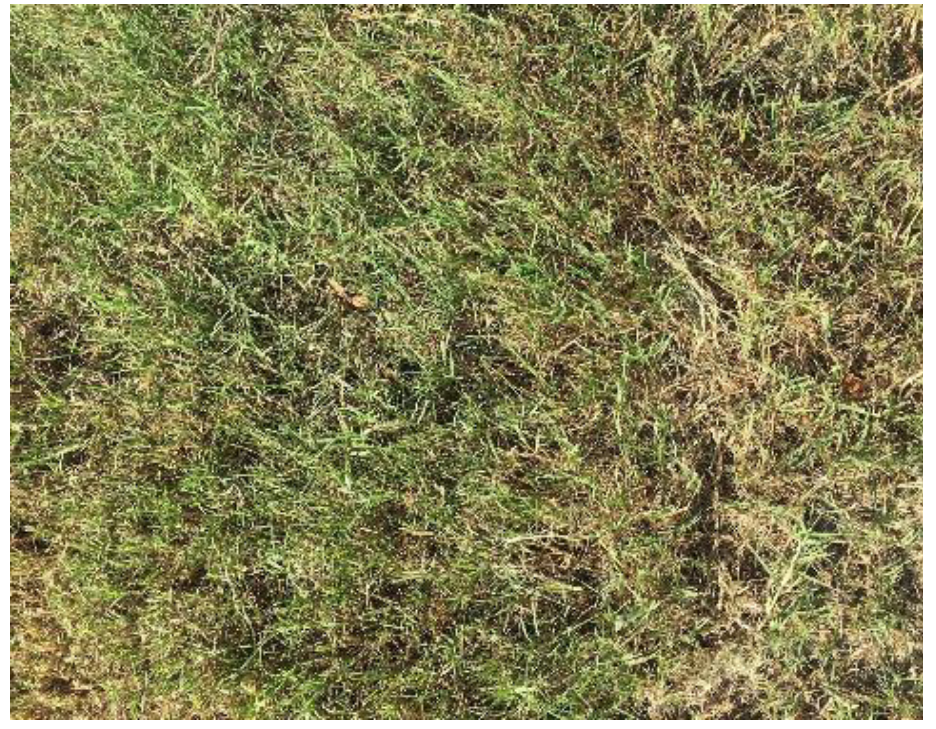

Figure 2. Common bermudagrass.

Credits: L. Trenholm, UF/IFAS 


\section{Maintenance of Bermudagrass}

\section{Lawns}

\section{Establishment}

Bermudagrasses are established vegetatively by planting sprigs, sod, or plugs and by seed as noted above. Each of these methods can be equally successful if the site is properly prepared before planting and if correct establishment practices are followed. For detailed information on lawn establishment, refer to the publication LH013, Establishing Your Florida Lawn (https://edis.ifas.ufl.edu/lh013).

Bermudagrass can be established any time of year in much of Florida, but in north Florida, the best time to establish bermudagrass is during the spring or early summer months. This enables the grass to establish before cooler weather begins, when growth is reduced. Seed may safely be sown until later in the year, but growth will be reduced in the fall. When establishing any grass, it is important to irrigate more frequently and for shorter durations than usual. Until a viable root system is established, turfgrass demands for water are greater, and irrigation is suggested if available. Multiple, short irrigations throughout the course of the day for 7-10 days following planting helps the grass establish without drying out. For the next 7-10 days, irrigate once a day to apply $1 / 4-1 / 2$ inch of water. After this, frequency should be reduced to 2-3 times weekly, again applying $1 / 4-1 / 2$ inch of water. Three to four weeks after sodding, the grass should be fully established and irrigation can begin on an as-needed basis. For more information, refer to ENH9, Watering Your Florida Lawn (https://edis. ifas.ufl.edu/lh025).

A newly planted lawn should not be fertilized until 30-60 days after planting. After 60 days, most turfgrasses will have established an active root system, which will allow nutrients to be applied with minimum risk of environmental impact. Waiting to fertilize will not affect turf health or establishment. The lawn should not be mowed until the roots have had a chance to peg down into the soil, generally 14-21 days after planting. Pegging means that the sod cannot be lifted without appreciable force.

\section{SPRIGGING}

The most common and least expensive method of planting bermudagrass is by sprigging. This is done mechanically over large areas or by hand in small areas. Fresh sprigs are rhizomes and stolons that have at least two nodes or joints. Sprigs are usually broadcast over an area at a rate of 200 to 400 bushels per acre, or 5 to 10 bushels per 1000 square feet, then pressed into the soil. Sprigging is less expensive than sodding, but does not produce an instant lawn as does sodding.

\section{SODDING}

Establishment of bermudagrass by sodding produces an instant turf surface. Sod should only be laid over bare soil that has been moistened, with pieces laid in a staggered bricklike pattern and the edges fitted tightly together to avoid any open cracks. Rolling and watering thoroughly will ensure good contact with the soil for fast rooting. Sodded areas should be watered two or more times per day with $1 / 4$ inch of water until the sod is held fast to the soil by roots (usually 2 to 3 weeks). After the root system has been established, the frequency of watering should be reduced, and the run times lengthened or changed on an as-needed basis.

\section{PLUGGING}

Sod can be cut into round plugs with a golf green cup cutter or into small squares with a machete. Spacing of plugs varies from 12 to 24 inches apart, with the closer spacing covering in 3 to 6 months and the farther spacing covering in 6 to 9 months.

\section{SEEDING}

Only common bermudagrasses can be established from seed. Bermudagrass seed should be planted at a rate of 1 to 2 pounds of hulled seed per 1000 square feet.

\section{Fertilization}

Proper fertilization is very important for sustaining a healthy lawn. Fertilization and other cultural practices influence the overall health and quality of the lawn and reduce its vulnerability to numerous stresses, including weeds, insects, and disease. It is important that anyone fertilizing their lawn be familiar with and follow the Florida-Friendly Landscaping ${ }^{\text {tm }}$ Best Management Practices (FFL BMPs). These practices are designed to maintain healthy lawns while minimizing potential environmental impact. There are state and local regulations that cover lawn fertilization, so be aware of city and county guidelines and always follow the directions on the fertilizer bag. For more information on BMPs, please refer to ENH979, Homeowner Best Management Practices for the Home Lawn (https://edis. ifas.ufl.edu/ep236).

Soil tests can be used to determine what adjustments, if any, should occur prior to or after planting. Most soil testing laboratories provide bermudagrass recommendations for soil $\mathrm{pH}$, salinity, and sodicity, which are based upon current evidence. If these recommendations are followed, one may 
observe a beneficial response. Soil testing may also provide reliable recommendations for phosphorus, but because most Florida soils are high in phosphorus, test results often indicate phosphorus applications are not warranted. Little to no evidence exists to warrant the use of soil test results when managing most other nutrients applied to turfgrass.

University of Florida recommendations call for applying $1 / 2$ pound to 1 pound of nitrogen per 1000 square feet of turfgrass per application with no more than $0.7 \mathrm{lb}$ of soluble $\mathrm{N}$ applied during any single application. Florida Rule (5E-1.003) allows fertilizer to be applied at rates of up to 2 pounds of nitrogen per 1000 square feet only in the spring or summer and only if applying a fertilizer that has at least $65 \%$ controlled release nitrogen. For information on determining how much fertilizer this is, please refer to ENH962, Figuring out Fertilizer for the Home Lawn (https:// edis.ifas.ufl.edu/ep221).

As a general rule, the first fertilizer application of the year should be early April in Central Florida and mid-April in North Florida. Nitrogen applications made prior to the last frost may result in damaged turfgrass. In South Florida, fertilizer applications may be made throughout the year since growth is year-round. University of Florida guidelines for lawn grass fertilization offer a range of fertilizer rates over which a particular species may be successfully maintained in the various regions of the state. The range of rates account for variability due to localized microclimatic effects, which can have a tremendous effect on turfgrass growth. An example of this would be a typical home lawn that is partially shaded and partially sunny. The grass growing in the shade needs less fertilizer than that growing in full sun. Fertilization is also affected by soil type, organic matter in soils, and practices such as clipping management. Recycled clippings provide some nutrients back to the turfgrass and may reduce the need for fertilizer inputs. Additionally, a newly sodded lawn on a sand soil with no organic matter may require more fertilizer than a lawn that has been established for years. In Florida, new homes and new developments may be adjacent to much older developed landscapes, and a one-size-fits-all approach to fertilization is not reasonable. In general, a lawn should be able to be maintained within this range of rates.

The fertilizer guidelines divide the state into three geographical locations as indicated in Table 1 . All rates are in pounds of nitrogen per 1000 square feet per year. For how to apply the correct amounts, refer to ENH962, Figuring out Fertilizer for the Home Lawn (https://edis.ifas.ufl.edu/ ep221).
On high-pH (>7.0) soils or where high-pH water is applied, yellow leaf blades may be an indication of iron or manganese deficiency. Granular or foliar applications of soluble or chelated manganese may provide a green-up in these cases. Iron should only be applied as a foliar spray or as a granular chelate.

\section{Mowing}

Proper mowing practices are necessary to keep a lawn healthy and attractive. Both height and frequency of cut need to be adjusted for the level of turf management and season of the year. Under low to moderate levels of management, bermudagrass should be cut at a height of 1 to 2 inches, which may require mowing one to two times per week. This will help the grass develop a deep root system and give it a better appearance. Under low to moderate management practices, mowing frequency should be adjusted to the amount of growth. Under higher levels of management, bermudagrass can be maintained at a height of $1 / 2$ inch, but this height will require more frequent mowing during the growing season. Mowing at this height and frequency requires greater inputs of fertilizer and water to maintain an attractive and durable turf. It should be noted that low cutting heights and high maintenance levels predispose the turf to many weed and pest problems. Regardless of maintenance level, remove no more than a third of the total leaf blade with any mowing.

A reel mower is preferred for cutting the fine textured bermudagrass cultivars that are mowed at heights below 1 inch. This gives a cleaner cut and these mowers can also be more accurately adjusted to low heights. Grass clippings can be left on turf maintained with low to moderate fertility levels if mowed at the proper height and frequency. The clippings do not contribute to thatch, and they provide supplemental sources of nutrients. Remove the clippings only if the amount is so excessive that clumps form or if appearance is important.

\section{Watering}

An established bermudagrass turf should be watered as needed to maintain green color. However, bermudagrass can persist during drought conditions but it will turn brown as it enters dormancy. The grass will turn brown and stop growing during this dormant period, but it will revive and resume growth upon irrigation with sufficient amounts of water. Irrigation can be applied when leaf blades begin to fold up, wilt, turn blue-gray in color, or when footprints remain visible after walking on the grass. Apply $1 / 2$ " to $3 / 4$ " of water per application. This will apply water to roughly the top 4-6 inches of soil, where the majority of roots are. To 
determine how much water a sprinkler system is providing, place several straight-sided cans (e.g., tuna fish or cat food) throughout each irrigation zone and then run the system to find out how long it takes to apply this amount of water. Each zone will likely take a different amount of time to fill the cans to the desired level. As such, this is how long your irrigation system should run for each zone. The recorded run times for each zone should then be programmed into the irrigation clock for automated systems. If the variation in the catch cans is great, a more thorough audit of the irrigation system is needed. Refer to ENH61, How to Calibrate Your Sprinkler System (https://edis.ifas.ufl.edu/ lh026).

\section{Pest Problems}

Common pest problems including insects and fungal diseases can affect bermudagrass. Diagnosis and recommendations for treatment of pest problems are available from your local UF/IFAS Extension office.

\section{Nematodes}

The most serious pest of bermudagrass in Florida are nematodes. Nematodes cause yellowing and general thinning of turf, especially during hot, dry periods. These pests cause extensive turf damage, particularly to turf grown on sandy soils or under high-maintenance regimes. Although some cultivars tolerate nematodes better than others, no cultivar is resistant to nematode infestation. Chemical nematode control is very limited for home lawns and usually requires commercial applicators. For more information on nematode management, refer to publication NG039, Nematode Management in Residential Lawns (https://edis.ifas.ufl.edu/ ng039).

\section{Insects}

Mole crickets are a major insect pest of bermudagrass. Other insects that cause damage in bermudagrass are sod webworms, armyworms, cutworms, grass loopers, and bermudagrass mites. There are many chemical controls available to treat insect pests, but these should be used only when necessary and in conjunction with sound cultural and fertility practices.

\section{Diseases}

Bermudagrass is subject to several diseases, including dollar spot, large patch, and Helminthosporium. A sound cultural program can minimize most disease problems, and fungicides can be used to cure major disease outbreaks. For more information on chemical control of diseases and their management please refer to publication PP-233, Homeowner's Guide to Fungicides for Lawn and Landscape Disease Management (https://edis.ifas.ufl.edu/publication/PP154) and SSPLP14 Turfgrass Disease Management (https://edis. ifas.ufl.edu/publication/LH040)

\section{Weeds}

Weed problems in bermudagrass turf are a sign that the turf has become weakened by improper management practices or damage from pests. Refer to the EDIS publication EHN884, Weed Management Guide for Florida lawns (https://edis.ifas.ufl.edu/ep141) for more information. Proper management practices can reduce most weed problems. If weeds are a persistent problem, herbicides labeled specifically for bermudagrass can be used for preemergence or postemergence weed control.

Table 1. Annual fertilization recommendations for bermudagrass in three regions of Florida.

\begin{tabular}{|c|c|}
\hline Location $^{1}$ & $\begin{array}{l}\text { N fertility guideline } 2 \\
\text { (lb N/1000 sq ft/year) }\end{array}$ \\
\hline North Florida & $3-5$ \\
\hline Central Florida & $4-6$ \\
\hline South Florida & $5-7$ \\
\hline
\end{tabular}

